Int. J. Speleol. 13 (1983), pp. 1-18.

\title{
Classification of Pseudokarst forms in Czechoslovakia
}

\author{
Jan Vítek*
}

SUMMARY

The paper is a geomorphological classif cation of pseudokarst forms in Czechoslovakia/Bohemien Massif and the Carpathians/. In the author's opinion, forms occurring in non-carbonate rocks, are morphologically and often genetically analogous to the forms of karst relief, and are pseudokarst phenomsna. They are divided according to their size into macroforms / in sandstone morphostructures of the Bohemian Cretaceous Basin some types of rocky valleys, water-shed plains and ridges, forming rock cities in some places/, mesoforms/ six types of caves, sinkholes, rock perforations and several rock phenomena/, and microforms/ weather pits and niches, lapies, etc./. The most prominent pseudokarst phenomena have been formed in the sandstones of the Bohemian Cretaceous Basin whose relief may be considerd "pseudokarst". They are also common in other sediments; in neovolcanic rocks and granitic rocks, as well as in ohter types of rocks. Pseudokarst forms are the product of geomorphological processes, especially weathering and denudation, block rock slides, erosion, suffosion, etc. Most of them have been developing in the recent mild humid climatic conditions.

Pseudokarst forms are surface as well as subsurface phenomena, morphologically and sometimes also genetically resembling the forms of karst relief. In geomorphology, however, they represent a substantial problem because of a varied interpretation and diversity in opinions as viwied from the petrographical and genetic positions. From a petrographical point of view rocks are traditionally divided into karst rocks' carbonates, especially limestones/, gypsum, rock salt, loess, some-

* Dr. Jan Vitek, Pedagog. fakulta Hradec Králové. Home adress: 56401 Zam berk, 1070, Czechoslovakia. 
times also ice, i.e. easily soluble rocks and non-karst rocks /rocks of low solubility or inssoluble rocks/. Genetic interpretation based on climatic-geomorphological conception stresses the that non-karst rocks are also affected in the respective climaticgeomorphological areas' or periods' by chemical influences of the aggressive water or solutions, i.e. by corrosion, which is considered to be a typical karst process. These problems have been treated of by Blanck' 1919', Klaer/ 1956/, Wilhelmy/ 1958/, Rasmusson' 1959/, Czudek et al.' 1964/, Panos/ 1965/,Hedges 1969/, Cigna/ 1978/, and others.

Naturally none of these interpretations can be fully accepted. Many transition phenomena are incidental to petrographical, lithological, structural or climatic-geomorphological conditions in the development of the relief. Within the territory of Czechoslovakia, in my opinion, the best criterion for the differentiation of pseudokarst phenomena is the petrographical composition of rocks. Even if chemical changes, which affect the structure of non-karst rocks in meso - or micro - relief, result in the origin of phenomena morphologically similar to the karst forms, they cannot be considered karst processes since their geochemical character is often quite different from the solution processes taking place in carbonates. Consequently, not every chemical change is a karst process. Mechanical as well as chemical influences partake in the origin of most of the surface and subsurface forms in non-carbonate rocks, which is the same in the origin of phenomena of karst relief. In Czechoslovakia only carbonates may be considered "karst rocks" since other karst rocks' with developed karst phenomena' do not occur on its territory.

Some clastic sediments containing a certain proportion of carbonate admixtures might have originated under the influence of the karst processes. Such forms were designated by Anelli' 1963' as "parakarst». In Czechoslovakia some forms of the relief in the carbonaceous conglomerates of the Carpathian flysch' e.g. Sulovské skály - Sulov Rocs', and in the calcareous sandstones and marlites of the Bohemian Cretaceous Basin may be considered parakarst or klastokarst forms.

Kosack' 1952/ tried a global synthesis of the distribution of pseudokarst forms on the Earth. Among the first authors treating the distinctive features of pseudokarst features of pseudokarst forms was Kunsky/ 1957/ who clossified pseudokars into lapies, sinkholes, several genetic and petrographical types of caves, and described pseudokarst hydrography and the importance of pseudokarst phenomena. In a similar way pseudokarst forms were classified in the USA where Halliday' 1960/ distinquished pseudokarst phenomena in volcanic rocks, on shores, 


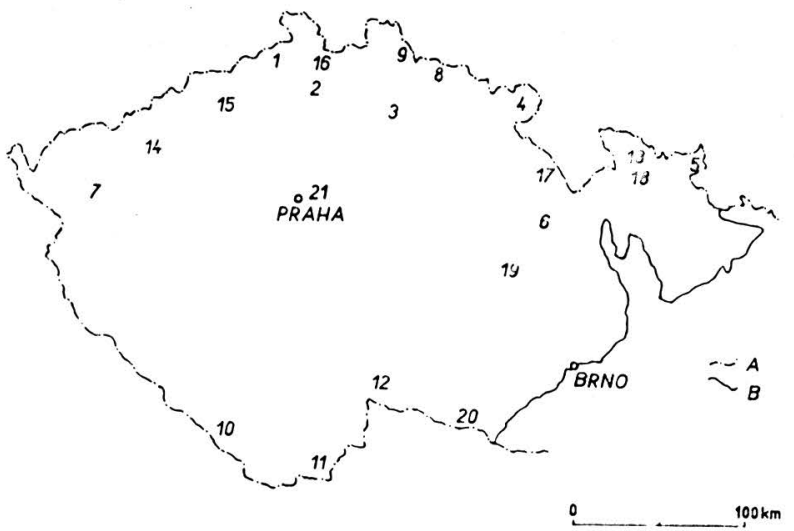

Fig. 1 - General map of the main localities of pseudokarst forms in Bohemian Massif. A - state frontier, B - boundary of the Bohemian Highland and the Carpathians.

Sandstones in the Bohemian Cretaceous Basin

1 - pseudokarst relief in the Decin Highland

2 - pseudokarst relief in the Ralsko Upland

3 - pseudokarst relief in the Jicin Upland - "Bohemian Paradise"

4 - pseudokarst relief in the Broumov Highland

5 - caves and sinkholes in the Zlate Hory Highland

Marlites in the Bohemian Cretaceous Basin

6 - caves and sinkholes in the Svitavy Upland

Paleogene sediments

7 - caves and sinkholes in the Sokolov Basin

Granitic rocks

8 tors and microforms in the Giant Mountains

9 - tors, caves and microforms in the Jizera Mountains

10 - tors and microforms in the Sumava Mountains

11 - tors, caves and microforms in the Nove Hrady Mountains, and Piedmont

12 - tors and microforms in the Javorice Highland

13 - tors and microforms in the Zulova upland

Neovolcanic rocks (basalt, phonolite))

14 - caves and rock perforations in the Doupov Mountains

15 - caves in the Central Bohemian Mountains

16 - caves in the Luzické (Lusatian) Mountains

Other types of rocks

17 - caves in the Orlice Mountains

18 - microforms in mica schists, quartzites, pegmatites in the Ash Mountains

19 - microforms in orthogneiss in the Zdár Highland

20 - caves in orthogneiss in the Dyje valley, Znojmo Highland

21 caves in lydites, Prague Upland 
in glaciers, and in loose sediments. Much attention has been paid predominantly to pseudokarst caves. Some authors/ e.g. Trimmel, 1968' do not differentiate between karst and pseudokarst caves but divide them according to the mode of their origin into primary' syngenetic/ and secondary' epigenetic/. Genetic problems of pseudokarst caves in Hungary have been studied by Ozoray/ 1962/, in Sweden by Tell/ 1963/. Caves found in lava were classified by Wood/ 1974/. From pseudokarst microforms much attention has been paid especially to lapies and rock perforations' Blanck, 1919, Klaer, 1956, Rasmusson, 1959, Ollier, 1969, and others'.

\section{GEOMORPHOLOGICAL CLASSIFICATION OF PSEUDOKARST FORMS IN CZECHOSLOVAKIA}

In establishing the typical features of pseudokarst forms criteria may be used. Most often, petrographical division into different kinds of rocks - in which individual forms occur - is applied; or genetic criterion' e.g. forms due to weathering, erosion, slope movements, etc,'; or morphological criterion. A geomorphological classification is probably most covenient because in different types of rockes morphologically similar forms may arise due to a joint effect of different genetic agents; most pseudokarst phenomena are of a polygenetic origin. In the following sections the author divides pseudokarst phenomena in Czechoslovakia according to their size into macroforms, mesoforms, and microforms. A survey of the geologial and geomorphological conditions in Czechoslovakia was compiled by Demek et t.' 1971 '.

\section{A/ Pseudokarst Macroforms}

In geomorphology no precise determination of pseudokarst macroforms has been established so far. In Czechoslovakia pseudokarst forms of different sizes and shapes occur only in the morphostructures of sandstones of the Bohemian Cretaceous Basin resembling the respective types of the morphostructures of karst relief. In these morphostructures (tablelands, cuestas, monoclinal ridges, etc.) which may be considered basic pseudokarst macroforms, pseudokarst phenomena form a considerable part of the relief so that we can speak of a pseudokarst relief. 


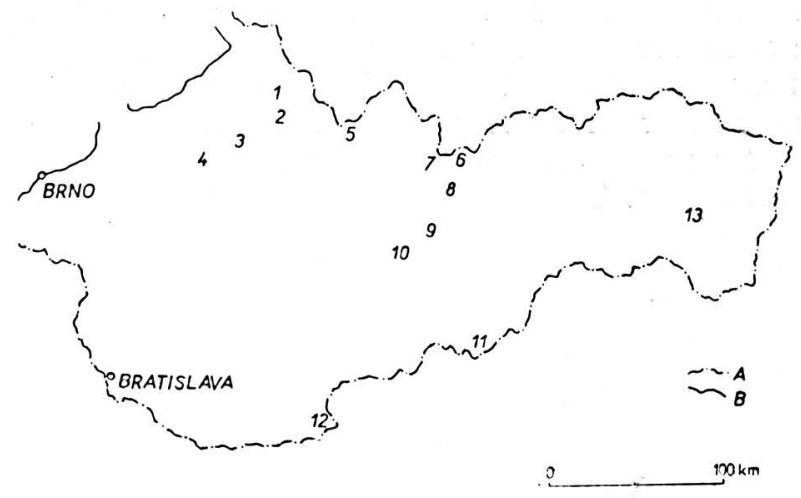

Fig. 2 - General map of the main localities of pseudokarst forms in the Carpathians. A - state frontier, B - boundary of the Bohemian Highland and the Carpathians.

Flysch sediments

1 - caves and sinkholes in the Moravskoslezeke Beskydy Mountains

2 - caves and microforms in the Javorníky Mountains

3 - caves and microforms in the Hostyn Mountains

4 - caves and microforms in the Chriby Mountains

5 - caves and sinkholes in the Slovakian Beskids

Granitic rocks

6 - caves and rock perforations in the Vysoke Tatry (High Tatra Mountains)

7 - sinkholes and rock perforations in the Západni Tatry (West Tatra Mountains)

8 - sinkholes in the Nizké Tatry (Low Tatra Mountains)

Neovolcanic rocks (endesites, agglomerates, basalts)

9 caves and rock perforations in the Polana Mountains

10 - different pseudokarst forms in the Kremnica Mountains, Vtácnik Mountains, Stiavnica Mountains, Krupina Mountains

11 - caves in the Cerová Mountains

12 - rock perforation in the Burda Mountains

13 - different pseudokarst forms in the Slanske Mountains 
Basin as well as in flysch sediments of the Carpathians. Smaller fissure-type caves occur also in neovolcanic rocks/ phonolite, basalt, andesite/ and mountainous areas in granitic rocks,/ e.g. in the High Tatra Mountains, Slovakia caves, more than 10 metres long have developed as a result of the decomposition of mylonite levels/. They are more rarely found in crystalline schists.

\section{Bedding-Type Caves}

They occur only in sedimentary rocks, their origin being due to destruction of bedding planes/ e.g. cracking off of thick rock benches, decomposition and washing away of lessresistant parts/. Bedding-type caves are usually low and wide. Morphologically resembling these may be caves in crystalline rocks developed along subhorizontal joints or cleavage planes though they genetically belong to fissure-type caves.

Numerous bedding-type caves are found in the sandstones of the Bohemian Cretaceous Basin. Some of them contain water achieving thus the character of spring-type caves/. e.g. Bartosova Pec, Jicínská pahorkatina - Jicín Upland, $30 \mathrm{~m}$ long/. Larger caves occur in Paleogene sediments in the valley of the Ohre in the Sokolov Basin/ Cikánka - Gipsy Cave/ smaller bedding-type caves have also been discovered in flysch sediments of the Carpathians.

\section{Cave Niches}

These occur in various types of rocks, their morphology differing a great deal. Some of them are wide having the character of overhangs, others are deeper and narrow. Most cave niches have developed in clastic sediments. Acc ${ }^{\circ}$ rding to their mode of origin they may be divided into two basic groups. The first group includes elliptical concave openings in rock walls which may be in fact widened and deepened joints/ of "tafoni" type/ formed below the solid crust of rocks in their less resistant layers. They are the product of differential weathering and rock denudation which is espeially due to chemical processes. Some of them are comparatively large with small openings leading to the surface. The second group of cave niches are 'verhangs/ «abri»/ in whose genesis especially mechanical force of weathering in less resistant layers/ system of right-angled joints, great abundance of joints, facies differences in the succession of strata, etc./. In the development of some cave niches, also, lateral erosion by river flows, suffosion and other geomorphological processes have taken part. 
gent joints. Such sets are more easily affected by destructive forces of weathering and erosion. The shape of the caves depends upon the orientation of joints. The caves are usually vertical, high and comparatively narrow.

Fissure-type caves occur in different types of rocks yet most often they are found in tectonically disturbed sediments. In the sandstone areas especially of the Bohemian Calcareous Basin differently large fissure-type caves have developed/ particularly in the Jicínská pahorkartina - Jicín Upland, the Decínská vrchovina - Decín Highland, and the Broumovská vrchovina - Broumov Highland/. For instance, in the Teplice Rocks/

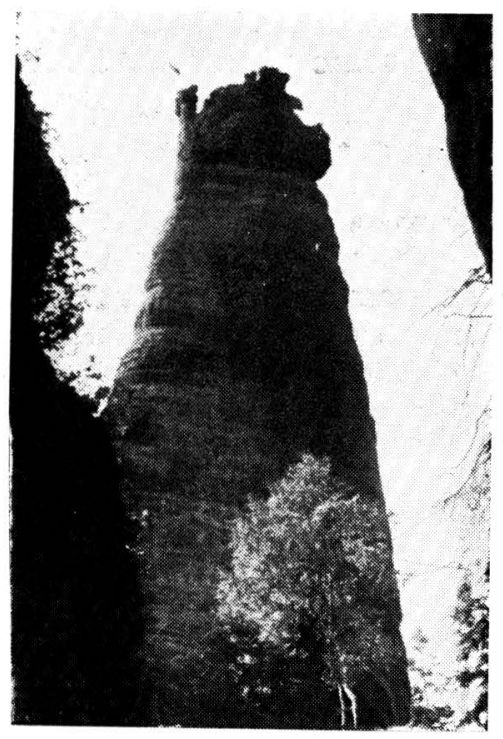

Fig. 3-Analogous forms to the tower karst are pinnacles and pillars in sandstone rock cities of the Bohemian Cretaceous Basin. Pinnacle in the Broumov Highland (Teplice Rocks) with lapies on top. Photo author.

Broumov Highland/ the cave called Skalní chrám/ Rocky Dome/ originated as a result of the destruction of Upper Cretaceous sandstones along joints/ orientation of joints $141^{\circ}-149 \%$. This cave is $45 \mathrm{~m}$ long and 1,2-2 $\mathrm{m}$ wide. In its front part it opens up to the surface of the sandstone plateau/ to a height of 50 $\mathrm{m} /$ so that it achieves the characcter of a rocky gorge passing backwards into a fissure-type cave. A few fissure-type caves have been formed also in marlites of the Bohemian Cretaceous 
Concave/ negative/ macroforms in this type of relief are represented by different valley forms especially canyons/ valleys with abrut rock wolls, foot-hill wastes or debris - or alluviumcovered floors/ and gorges/ narrow volleys with rock walls in the whole relief/. Rocky valleys developed along prominent joint systems are common phenomena in all rocky areas of the Bohemian Cretaceous Basin/ Decínská vrchovina - Decín Highland, Ralská pahorkatina - Ralsko Upland, Jicínská pahorkatina - Jicín Ubland, Broumovská vrchovina - Broumov Highland/. Occurrences of other valley pseudokarst forms/ blind, half-blind/are only occasional.

Of the convex/ positive/ pseudokarst macroforms in the sandstone macrostuctures of the Bohemian Cretaceous Basin - according to my opinion - the most impcrtan $i$ are water-shed plains and ridges forming in some places isolated pillars and cones the «rock cities" - which are a morphological analogy of the forms of the tower karst/ Fig. 3/.

\section{B/ Pseudokarst Mesoforms}

The occurrance of pseudokarst meso - and micro-forms is restricted to the surface of plateaus and rocks scarps.

Pseudokarst mesoforms in different types of rocks include caves, sinkholes, larger rock perforations and some other rock forms.

\section{Caves}

All pseudokarst caves in Czechoslovakia are epigenetic/ secondary/ caverns developed under the influence of weathering and rock denudation, slope deformations/ block slides, collapses and waste accumulations/ or other geomorphological processes such as fluvial lateral erosion, suffosion, etc./. Most caves have developed in clastic sediments due to their favourable structural properties/ non-homogeneity, tectonic disturbances, deposition conditions, permeability, etc./. According to their manner of genesis and morphology pseudokarst caves in Czechoslovakia may be divided into six groups: fissure-type caves, bedding-type, cave niches, crevice-type cav€s, talus-type caves and combined-type caves.

\section{Fissure-Type Caves}

Their origin depends upon the existence of prominent vertical/ or inclined/ joints sets represented by parallel or conver- 
In sandstones of the Bohemian Cretaceous Basin large cave niches occur, such as in the Klokcské skaly/ Klokoc Rocks/, Jicinská pahorkatina - Jicín Upland; here the cave called Postojná/ $262 \mathrm{~m}^{2} /$ originated through the combination of several

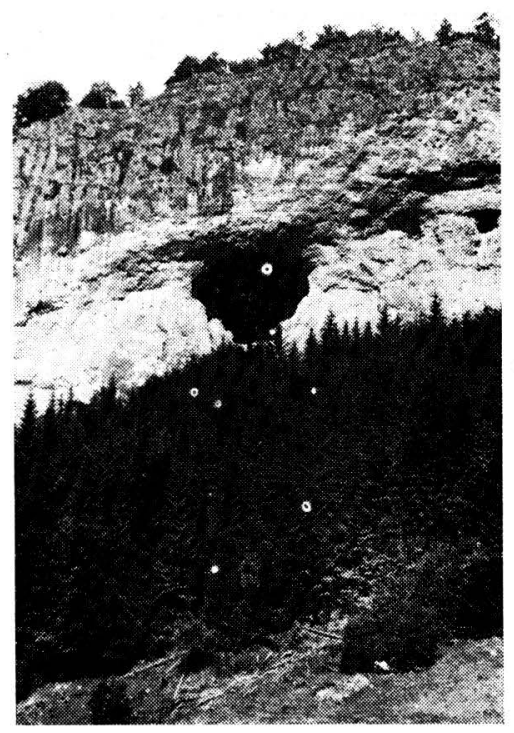

Fig. 4 - Cave niche "Absina" in andesite agglomerates, Polana Mountains. Photo author:

smaller niches of the "tafoni" type. Caves niches in sandstones of the Decínská vrchovina/ Decín Highland/ and the Ralská pahorkatina/ Ralsko Upland/ are mostly of a character of a wide overhangs. Smaller cave niches have been formed also in marlites of the Bohemian Cretaceous Basin, in flysch sediments of the Carpathians, in Carboniferous, Permian and $\mathrm{Pa}$ leogene sediments (arkoses and conglomerates). Numerous smaller cave niches have been formed by destruction of granitic rock forms/ Jizerské hory - Jizera Mountains/; and in crystalline schists/ Orlické hory - Orlice Mountains/, in lydites/ Prazská plosina - Prague Upland/, in quartzites, amphibolites, effusive rocks/ Polana - Pclana Mountains, Doupovské hory Doupov Mountairıs, (Fig. 4) and other types of rocks.

\section{Crevice-Type Caves}

They have been mostly produced by the movements of large blccks in different types of compact rocks arising as cracks, 
these are widened along tectonic contacts/ exceptionally also along bedding planes/ and clefts/ not of tectonic nature/ by the breakdown of blocks of rock. In their initial stage the openings are narrow and high/ achieving sometimes the character of vertical pits of a roof-like or V-shaped cross section, dependent upon the mode of the rock block slide; the roof is formed by the highersituated blocks of rock/. Apart from the gravity slope failures other geomorphological influences, e.g. rock decomposition, collapses, and block accumulation also contribute to their formation.

Numerous crevice-type caves and vertical pits have been formed in the flysch sediments of the Carpathians, especially in the Moravskoslezké Beskydy/ Moravo-Silesian Beskids/ e.g. the cave "Cyrilka», $350 \mathrm{~m}$ long, the abyss "Na Knehyni", $56 \mathrm{~m}$ deep, in the Slovenske Beskydy/ Slovakian Beskids/, in the Hostynské vrchy/ Hostyn Mountains/, in the Javorníky/ Maple Mountains/, in the Javorniky/ Maple Mountains/, in the Vizovická vrchovina/ Vizovice Mountains/, etc. More than $100 \mathrm{~m}$ long crevice-type caves may also be found in marlites of the Bohemian Cretaceous Basin/ Svitavská pahorkatina - Svitavy Upland/ as well as in sandstone morphostructures. In the Bohemian Massif/ Ceské stredohorí - Central Bohemian Mountains, Luzické hory - Lusatian Mountains/ and in the Carpathians/ Cerová vrchovina - Cerová Mountains/, crevice-type caves are the result of decomposition of neovolcanic rocks. Larger caves occur in orthogneiss rocks in the Dyje valley/Znojemská vrchovina - Znojmo Highland/ Fig. 5/.

Crevice-type caves also occur in great abundance in areas composed of carbonaceous rocks where they may be affected be karst processes, and often display a rich sinter decoration / frequently being included in the forms of karst relief/. They arise, for instance. as a result of destruction of fragmets of dolomite nappes in the upper series of the West Carpathians, or are produced by the cambering processes in the travertine elevations.

\section{Talus-Type Caves}

These caves are in fact free spaces formed between boulders and rock block debris distributed on the floor of some rockwalled valleys, or in stone fields and piles of boulders. The origin of is often attributed to cryogenetic disintegration which took place in the periglacial conditions of the Pleistocene Glacial periods. Some types of debris, however, date from the Holocene. The spaces between the boulders are of quite irregular shapes and profiles, wider passageways alternating with the 
"fat man's miseries" and "squeezes", some of which are passable for several hundreds of metres. This type of cave is sometimes called a "pseudocave".

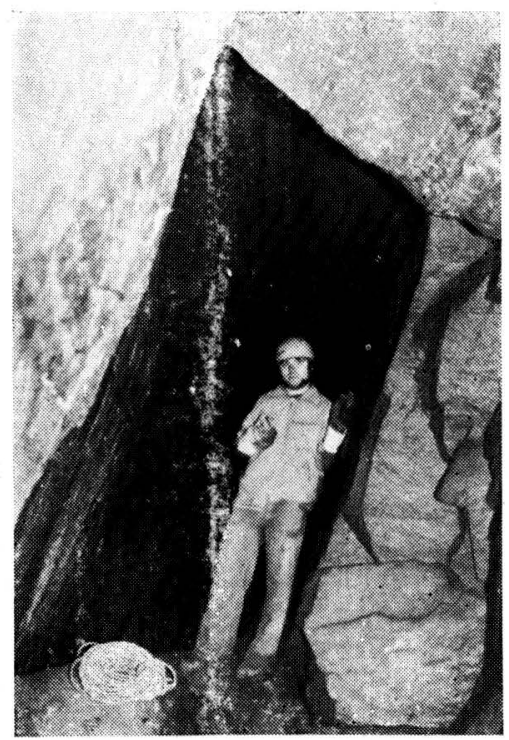

Fig. 5 - Crevice-type cave in the orthogneiss slope of the Dyje valley near Vranov (Znojmo Highland).

Photo author.

Talus-type caves of larger dimensions maybe found in sandstone areas of the Bohemian Cretaceous Basin/ Broumovská vrchovina - Broumov Highland, Ralská pahorkatina - Ralsko Upland/; in granitic rocks/ Vysoké Tatry - High Tatra Mountains, Jizerské hory - Jizera Mountains, etc./; and in neovolcanic rocks/ Ceské stredohorí - Central Bohemian Mountains, Cerová vrchovina - Cerová Mountains, etc./.

\section{Combined-Type Caves}

The origin and development of combined-type caves has been affected by at least two genetic agents whose influence was of a different intensity at different times. The resulting shape of the cave always displays strong morphological traces of the respective genetic types. 
Combined-type caves may be found i ndifferent types of rocks Quite frequent are combinations, e.g. fissure-and bedding-type caves/ sandstones in the Bohemian Cretaceous Basin/; fissure-and talus-type caves/ sandstones, granitic rocks, neovolcanic rocks/; crevice-and talus-type caves, fissure-and crevice-type cacves; and cave niches and talus-type caves, etc.

\section{Sinkholes}

According to the mode of their origin as well as morphology, sinkholes and similar sink-shaped concave forms in non-karst rocks may be divided into two basic groups:

1/ Sinkholes due to the process of suffosion subsidences, elliptical in outline or elongated along prominent fissures.

2/ Sinkholes due to slope deformations/ especially block rock slides/; they are elongated shape and mostly parallel to the slope. Combinations of both types may also be found.

Sinkholes situated in the Bohemian Highland, especially in sandstones of the Bohemian Cretaceous Basin/ Jicínská pahorkatina - Jiccín Upland/ whih are due to suffosion subsidence were described by Kunsky, 1957, Balatka, Sládek, 1969, Král, 1975, Sweeting, 1972. They are leas frequent in Upper Cretaceous marlites or Paleogene sediments/ Sokolovská pánev Sokolov Basin/ and in neovolcanic elevations etc.

Sinkholes and similar depressions formed in slopes as a results of rock block slides occur especially in the West Carpathians/ Kunsky, 1957, Nemcok et al., 1977/, e.g. in the High Tatra Mountains, the Low Tatra Mountains, the West Tatra Mountains, the Slovakian Beskids, etc. in different types of rocks/ crystalline rocks and sediments/. Smaller sinkholes formed as a result of the rock block slides may be found also in various other places in the Bohemian/ sandstone and marlites in the Bohemian Cretaceous Basin.

\section{Rock Perforations}

Rock perforations/ openings/, such as rock arches, natural bridges, windows and tunnels are pseudokarst meso - and micro - forms commonly observed in the Bohemian Highland and in the Carpathians. Rock arches are openings in rocks of larger dimensions where at least one side of the arch is firmly rooted in the rock substratum. The roof of the arch or natural bridge is usually situated at the level of the surrounding land, Windows are mostly smaller opinngs, nct reaching down to the rock 
base. Tunnels are underground openings, usually long, low and narrow. Rock perforations in non-karst rocks are mostly the product of differential weathering processes and rock denudation, such as the joining of two opposite-lying rock niches or slender pillars at the crossings of joint sets.

Rock arches may be found in clastic sediments/ especially in the sandstones of the Bohemian Cretaceous Basin/ where they are particularly large. One of the most extensive sandstone rock arches/ natural bridges/ in Europe is the Pravcice Gate, Decínská vrchovina - Decín Highland'. The arch of the bridge is $16 \mathrm{~m}$ high and $27 \mathrm{~m}$ wide, and $3 \mathrm{~m}$ thick. Rock arches of smaller size occur also in the Ralská pahorkatina/ Ralsko Upland/, the Jicínská pahorkatina/ Jicin Upland/ and in the Broumovská vrchovina/ Broumov Highland/. In other types of rocks, arches are not common.

Windows are frequently forms of selective weathering in different types of rocks. They exist in large numbers in sandston areas of the Bohemian Cretaceous Basin. They are also frequent in pyroclastic neovolcanic rocks of the Carpathians/ Slánské vrchy - Slanské Mountains, Vtácník - Vtácník Mountains, Stiavnické vrchy - Stiavnice Mountains, etc./. They are not so frequent in other types of rocks, but do occur in granitic rocks in tectonically disturbed beds as a result of the exfoliation as well as the decomposition of xenolith bodies; and in crystalline schists along joint and foliation planes, etc.

Tunnels occur predominanly in sandstones of the Bohemian Cretaceous Basin, in tectonically disturbed granite/ the Tatra Mountains/, in crystalline schists/ Zdárské vrchy - Zdar Highland/, and in pyroclastic neovolcanic rocks.

\section{Rock Phenomena}

Convex/ positive/ mesoforms are usually - quite unjustly not included in the pseudokarst forms; this is most probably due to the difficulty with which they may be recognised. In my opinion, several other isolated rock forms/ of the "tors" type/ not differing genetically from similar forms of karst relief / Panos. 1965/ should be included in pseudokarst forms. This is especially true of rock forms of shapes which are due to the forces of selective weathering.

In the pseudokarst relief of sandstone morphostructures of the Bohemian Cretaceous Basin, mushroom rocks may be included in pseudokarst forms. They are produced by differential weathering which etches out weaker parts of the rock along the succession of sandstone strata. 


\section{C/ Pseudokarst microforms}

Pseudokarst forms include various microforms which are the result of rock decomposition and denudation. Their morphological analogy may also be found on rocky surface of karst relief, yet they often occur in greater abundance and morphological variety in non-karst rocks. They include rock cavities, rock niches, lapies and weather pits/ pan-holes/.

\section{Rock Cavities and Rock Niches}

Deep and shallow elliptical rock cavities and rock niches of various types/ of smaller size than cave niches/ occur in vertical, inclined or hanging rock walls. They are found in different types of rocks, especially in clastic sediments.

Rock cavities and rock niches of different shapes and dimensions are typical forms of microrelief in rocky areas of the Bohemian Cretaceous Basin. Some of them are shallow, others are incised deeply into the solid crust of the rock. They often form large systems and honeycombing patterns. Most authors consider these forms to be the product of selective denudation due to mechanical, chemical and biological decomposition and deflation of sandstones. Large numbers of these microforms are concentrated in the "rock cities" of the Decínská vrchovina/ Decín Hinhgland/, the Ralská pahorkatina/ Ralsko Upland/, the Jicínská pahorkatina/ Jicín Upland/ and the Broumovská vrchovina/ Broumov Highland/. They are quite frequent in some analogous types of sediments, such as in flysch sandstones and conglomerates in the Carpathians and in Permian and Carboniferous arkoses and greywackes, etc.

Somewhat different types of rock cavities and rock niches may be found in granitic rocks. Of special prominence are rock cavities of the "tafoni" type/ Blanck, 1919, Klaer, 1956/ which originate below the solid crust of the rock surface in vertical and hanging rock walls. They are the product of chemical as well as mechanical changes in which less resistant parts below the protecting crust/ mostly composed of limonite/ are weathered away, thus leaving pits widening inwards. Small occurrences of rock cavities and rock niches in granitic rocks of the Bohemian Massif may be found/ Demek, 1964, Czudek et al., 1964, Votypka, 1970, etc./ in the Zulovská pahorkatina/ Zulová Upland/, the Javorická vrchovina/ Javorice Highland/, the Sumava/ Bohemian Fores/, the Jizerské hory/ Jizera Mountains/. Shallow rock cavities and niches of different shapes occur in crystalline schists, pegmatites, andesites, etc. 
Lapies/ Karren/ are comparatively frequent microforms in certain types of non-karst rocks. Morphologically and often also genetically, they are similar to lapies of karst relief. They originate as a result of chemical, mechanical/ biochemical and biomechanical/ weathering processes. Terms denoting pseudokarst lapies may equally be applied for lapies of the karst relief/ Bögli, 1960, Sweeting, 1972/.

In Czechoslovakia in areas composed or granitic rocks, channel lapies/ Rinnenkarren/ have developed forming deep grooves divided by rounded ridges or the inclined rocky surface. Their origin is due/ Klaer, 1956, Czudek et al., 1964/ to the joint effect of mechanical erosion by rain water and chemical rock decay. In granitic rocks of the Bohemian Massif channel lapies have been found, for instance, in the Jizerské hory/ Jizera Mountains/, in the Zulovská pahorkatina/ Zulová Upland/, in the Javorická vrchovina/ Javorice Highland/, etc. Less prominent channel lapies occur in orthogneiss/Zdárské vrchy - Zdár Highland/ as well as isolated in quartzites/ Jeseníky - Ash Mountains/.

Different types of lapies have been found in the sandstone areas of the Bohemian Cretaceous Basin/ Balatka et al., 1969, Vítek, 1979a/. They may be divided into channel lapies/ channels divided by continuous or partial ridges/ formed by the mechanical or chemical activity of aggressive water; pit lapies whose development has also been affected by the destructive action of vegetation roots as well as by biochemical influences, and step lapies/ Trittkarren/ formed in inclined rock plates along bedding joints, /Vitek, 1982/.

\section{Weather Pits}

Weather pits/ bowls, panholes/ are elliptical openings in the surface of horizontal or gently inclined rock plates. They many be found in different types of rocks, especially in granitic rocks and sandstones. Similar solution pits in carbonate rocks are called Kamenitsas.

Classic studies on weather pits have been so far concerned with areas composed of granitic rocks where they are the most commonly observed microforms. In the opinion of some contemporary authors/ Klaer, 1956, Czudek et al., 1964, Hedges, 1969, Ollier, 1969/ weather pits are the result of complicated weathering processes and rock denudation; individual development phases occur and important role is played by mechanical 
changes/ separation of mineral grains by micro-frost action, chemical effects/ decomposition of some minerals, e.g. biotite/, and biochemical effects. changes in the quality and the $\mathrm{pH}$ of water stagnating on floor of the weather pits/.

In the granitic rocks of the Bohemian Massif perfectly developed weather pits may be found in the Jizerské hory/ Jizera Mountains/, the Krkoncse/ Giant Mountains/, the Ceskomoravská vrchovina/ Bohemian-Moravian Highand/, the Sumava/ Bohemian Forest/, the Zulovská pahorkatina/ Zulová Upland/, etc. They are quite frequent in the Upper Cretaceous sandstones of the Bchemian Cretaceous Bisin/ Broumovská vrchovina - Broumov Highland, Luzické hory - Lusatian Mountains, etc./, in the flysch sediments of the Carpathians, in Carboniferous arkoses, etc. They also occur in other tvpes of rocks, such as mica schists/ Jeseniky - Ash Mountains/, orthogneiss /Zdárské vrchy - Zdár Highland/, pegmatites and quartzites /Jeseníky - Ash Mountains/.

\section{ZUSAMMENFASSUNG}

Der Beitrag betrifft die geomorphologische Klassifizierung der Pseudokarstformen in der Tschechoslovakei/ in der Böhmischen Masse und in den Karpaten/. Der Verfasser hält für Pseudokarstformen in der Tschechoslovakei solche in den Nichtkarbonaten entstandenen Formen, die sich als morphologische, bzw. genetische analogie der Karstreliefsformen zeigen. Der Dimensionsabstufung entsprechend, teilt man die Pseudokarstformen folgendermassen: 1. Makroformen/ irgendmanche typen von Felsentälern in den Sandsteinmorphostrukturen des Böhmischen Kreidebeckens: stellenweise als die "Felsenstädte" gegliederte Wasserscheideplateaus und Kämme; 2. Mezzoformen/sechs Grottentypen, "Dolinen", Felsenperforationen und irgendmanche Felsenformen/; 3. Mikroformen/ Felsennischen, "Tafoni" Bröckellöcher, Karren und Felsennäpfe/. Besonders vollkommen entwickelte Pseudokarstformen der Ausmass - und Gestaltskala finden sich in den Sandsteinen des Böhmischen Kreidebeckens, wo man schier über ein "Pseudokarstrelief" sprechen kann. Häufig findet man die Pseudokarstformen auch in den an deren Sedimenten, Neovulkaniten, Granitoiden, vereinzelt auch in anderen Gesteintypen. Die Pseudokarstformen sind als Produkt der geomorphologischen Prozesse, namentlich der Gesteinsverwitterung und Abtragung, der Hangblockbewegung, Erosion, Suffosion usw, entstanden. In den allermeisten Fällen entwickeln sich die Pseudokarstformen in den rezenten Bedingungen des mässig feuchten Klimas..

\section{REFERENCES}

ANELL.I, F. 1963 - Fenomeni carsici, paracarsici e pseudocarsici. An. Mus. Geolog. di Bologna, 2, v. XXXI: 11/25.

BALATKA et al. 1969 - Vvvoj piskovcového reliéfu Ceské tabule na prikladu Polomennvch hor./ The Development of the Sanstone Relief of the Bohemian Plateau in the Polomenne Hills/. Rozpravy CSAV, r. MPV 79:5:3/38. Academia, Praha. 
BALATKA, B. and SLADEK, J., 1969 - Závrty v nekrasovych horninách Ceské vysociny. (Sinkholes in Non Karst Rocks of the Bohemian highland). Zprávy Geogr. Ustavu CSAV, 6:8:1/9. Brno.

BLANCK, E. 1919 - Verwitterungskundliche Studien zum Tafoni und Karren - Problem im Mittelgebirge. Inter.Mitt.f.Bodenkunde, 8:32/71, 179 /234, Berlin-Wien.

BOEGLI, A. 1960 - Kalkosung und Karrenbildung. Zeitschr.f.Geomorph., Supp. 2:4/21. Göttingen.

CIGNA A.A., 1978 - A Classification of Karstic Phenomena. Inter. J. Speleol., 10:3/9. Milano.

CZUDEK, T. et al., 1964 - Verwitterungs- und Abtragungsformen des Granits in der Böhmischen Masse. Peterm.Geograph.Mitt., 108:182/192. Gotha.

DEMEK, J. 1964 - Castle Koppies and Tors in the Bohemian Highland. Biul. Peryglacial., 14:195/216. Lodz.

DEMEK, J. et al. 1971 - The Geography of Czechoslovakia. Academia, Praha. $330 \mathrm{p}$.

HALLIDAY, W.R., 1960 - Pseudokarst in the United States. Bull. Nation. Speleol.Society, 22:109/113. Arlington.

HEDGES, J. 1969 - Opferkessel. Zeitschr.f.Geomorph., 13:22/55. BerlinStuttgart.

KLAER, W. 1956 - Verwitterungsformen im Granit auf Korsika. Ergänz. Peterman.Geograph.Mitt., 261:1/146. Gotha.

KOSACK, H.P. 1952 - Die Verbreitung der Karst und Pseudokarst-erscheinungen über die Erde. Peterman.Geograph.Mitt., 96:16/22. Gotha.

KRÁL, V. 1975 - Sufoze a její podíl na soucasnych geomorphologickych procesech v Cechách. (Der Anteil der Suffosion an den aktuellen geomorphologischen Prozessen in Böhmen). Acta Univ.Carolin., 1-2:23 /30. Praha.

KUNSKY, J. 1957 - Types of Pseudokarst Phenomena in Czechoslovakia. Céskoslov.Kras. 10:108/125. Praha.

NEMCOK, A. et al. 1977 - A Survey of the Research of Slope Deformations in Individual Regions of Czechoslovakia. Bull. Internat.Assoc.Engineer.Geol., 15:59/62. Krefeld.

OLLIER, C.D. 1969 - Weathering. Olier and Boyd, Edinburgh. 304 p.

OZORAY, G. 1962 - The Genesis of Non-Karstic Natural Cavities as Elucidated by Hungarian Examples. Karst-és barlang., 2 (1960):127/136. Budapest.

PANOS, V. 1965 - Problém krasovení nekarbonátovych hornin (Problem of Karstification of Non-Carboniferous Rocks). Casop.Mineral.Geo log., 10:105/109. Praha.

RASMUSSON G., 1959 - Karstformen im Granit des Fichtelgebires. Höhle, 10:1/4. Wien.

SKRIVÁNEK, F., RUBiN J. 1973 - Caves in Czechoslovakia. Academia Praha. $136 \mathrm{p}$.

SWEETiNG, M.M. 1972 - Karst Landforms. Macmillan, London and Basingstoke. $362 \mathrm{p}$.

TELL, L. 1963 - Die Höhlentypen Schwedens. Internat.Kongress f. Spelëol., 2:1:251/254. Wien.

TRIMMEL, H. 1968 - Höhlenkunde. F. Vieweg und Sohn, Braunschweig. $308 \mathrm{p}$.

VITEK J., 1979 - Pseudokrasové tvary v kvádrovych pískovcich sv. Cech. (Pseudokarst Phenomena in Block Sandstones in North-East Bohemia). Rozpravy CSAV, c.MPV, 89. Praha.

VITEK J., 1980 - Typy pseudokrasovych jeskyni v. CSR. (Type of Pseudokarst Caves in Czechoslovakia). Ceskoslov. Kras, 30 (1978): 17/28. Praha.

VITEK J., 1982 - Karrentypen in den Quadersandsteinen des Böhmischen Massivs. Petermanns Geograph. Mitt., 126: 17/21. Gotha. 
VOTYPKA, J. 1970 - Ukázky zvetrávaní zul Ceského masivu. (Beispiele der Granitverwitterung im Böhmischen Massiv). ActaUniv.Carol., Geograph., 2:75/91. Praha.

WILHELMY, H. 1958 . Klimamorphologie der Massengesteine. Braunschweig. $238 \mathrm{p}$.

WOOD, C. 1974 - The Genesis and Classification of Lava Tube Caves. Transact.Brit.Cave Assoc., 1:15/28. 